\title{
The Process of Adopting Organic Agriculture Technology by Rice Farmers in the Sri Rejeki Farmers Group, Godean, Sleman
}

\author{
Indardi ${ }^{1, *}$, Nurul Anggita Rahmawati ${ }^{1}$ and Siti Yusi Rusimah ${ }^{1}$ \\ ${ }^{1}$ Department of Agribusiness, Faculty of Agriculture, Universitas Muhammadiyah Yogyakarta
}

\begin{abstract}
The research objective was to describe the adoption process in the application of organic agricultural technology. The research was conducted in Brongkol, Sidomulyo Village, Godean, Sleman. This research uses descriptive analysis, qualitative paradigm. Data were collected by indepth interviews and observations on farmers who have received guidance on organic farming technology through field schools until they are saturated with information (20 respondents). Research results, at the awareness stage respondents are familiar with information on organic farming technology some were long before, sometime before, during implementation, and there were farmers who knew some time after the field school. The interested stage, respondents seek additional information through their friends. The evaluation stage is the stage when respondents begin to seriously assess. The process of the length of evaluation conducted by farmers is quite diverse. In the trial phase, respondents applied it to their land, with various sizes. The adoption stage, generally respondents accept to apply technology, there is a small proportion who do not continue the adoption. It is important to do intensive counselling.
\end{abstract}

\section{Introduction}

Agriculture plays an important role in economic growth, enhancing food security, poverty reduction and rural development [1]. Organic farming could provide sustainable livelihood to rural mass with ensuring food security and protecting the environment in the long run [2]. Organic farming is an environmentally sound technology without chemical input. In global, there are more than 180 countries were successfully practicing organic farming [3]. Organic agriculture combines tradition, innovation and science to benefit the shared environment and promote fair relationships and a good quality of life for all involved [4]. Currently there are still many farmers who use inorganic agriculture to support farming activities, with the use of chemical pesticides and fertilizers which cause environmental damage [5]. This has resulted in numerous human health and environmental hazards, compromising food safety [6]. Degradation of soil fertility due to over use of land and chemical fertilizer are critical factors affecting sustainability agricultural systems [7]. Conventional farming is the cultivation process where synthetic pesticide and chemical fertilizers are applied to gain

\footnotetext{
*Corresponding author: indardi@umy.ac.id
} 
higher crop yield and profit [8]. Organic farming improved the soil quality [9]. Development of organic farming was quite fast in the mid-1970s due to the awareness of the impact of environmental damage caused by the use of fertilizers and chemicals during the green revolution era in the 1960s. The application of organic agriculture can restore soil fertility and reduce greenhouse gas emissions. The development of organic agriculture in Indonesia is due to the increasing consumer demand for organic products [10]. Currently, organic rice farming gains a lot of attention and is implemented in several regions in Indonesia [11]. The demand for organic products is expected to increase in the future along with the increasing public awareness of safe and healthy food [12]. It implies that the organic farming has a good prospect in forthcoming years [13]. In the recent years, organic farming is gaining more and more importance as it is found to be a sustainable method of farming and it has also resulted in an increased income source of smallholder farmers [14].

As a staple food, the availability of rice is essential for Indonesian people [15]. Yogyakarta is one of the regions of Indonesia which has quite extensive agricultural land. Of the 5 districts in DIY, Sleman Regency has the largest agricultural land compared to other districts, amounting to 21,841 hectares from 55,292 hectares (39.5\%) in 2016. Godean is a food barn in Sleman Regency. The Sri Rejeki Farmer Group is one of the farmer groups in Godean District, Sleman Regency, which has received guidance regarding the organic rice farming system through field schools held in 2017. However, until now there are still some members of the Sri Rejeki farmer group who have not implemented the system organic agriculture. There are even farmers who decide to return to implementing conventional farming systems. Farmers encountered problems in production, certification and marketing aspects of organic agriculture [16]. Based on this description, it is deemed necessary to conduct a study on how the adoption process has been running in the Sri Rejeki Farmer Group in Godean District, Sleman.

Sustainable agricultural technologies are being touted as a requirement for a sustainable world in many parts of the globe [17]. The use of agricultural technology, such as highyielding seed varieties in developing countries where the primary source of livelihood is agriculture is vital in reducing poverty, hunger, and promoting food security [18]. The organic farming system is a holistic farming system that aims to improve the health of agro ecosystems including biodiversity, biological cycles, and soil biological activities to optimize crop production [19]. Organic agriculture is defined as "a production system that sustains the health of soils, ecosystems and people [20]. Organic operation can contribute to a sustainable food production system, improve the employment opportunities, especially for women, improve household food security, enhance biodiversity, and contribute to agricultural development [21]. In this system soil fertility is seen as the key to successful production [22]. Organic farming is a form of agriculture which excludes the use of synthetic fertilizers, pesticides and plant growth regulators [23]. The main focus of the Organic farming system is on the utilization of organic matters for improvising the quality of soil, reducing health hazards related to the food chain and to accomplish closed nutrient cycles [24]. These four principles are applied in the agricultural sector in a broad sense. This includes how humans care for land, water, plants and animals to produce, prepare and distribute food and other products. This principle deals with how humans relate to the environment, relate to each other and determine the legacy for future generations. Romauli \& Fauzia [25] stated that organic agriculture is a farming activity that is friendly to the environment and tries to minimize negative impacts on the surrounding environment, justice and protection. The farmers' attitude toward environmental concern was the most important reason for adopting organic rice farming [26]. These four principles are applied in the agricultural sector in a broad sense. This includes how humans care for land, water, plants and animals to produce, prepare and distribute food and other products. This 
principle deals with how humans relate to the environment, relate to each other and determine the legacy for future generations. Romauli \& Fauzia [25] stated that organic agriculture is a farming activity that is friendly to the environment and tries to minimize negative impacts on the surrounding environment. Justice and protection. These four principles are applied in the agricultural sector in a broad sense. This includes how humans care for land, water, plants and animals to produce, prepare and distribute food and other products. This principle deals with how humans relate to the environment, relate to each other and determine the legacy for future generations. Romauli \& Fauzia [25] stated that organic agriculture is a farming activity that is friendly to the environment and tries to minimize negative impacts on the surrounding environment. This principle deals with how humans relate to the environment, relate to each other and determine the legacy for future generations. Romauli \& Fauzia [25] stated that organic agriculture is a farming activity that is friendly to the environment and tries to minimize negative impacts on the surrounding environment. This principle deals with how humans relate to the environment, relate to each other and determine the legacy for future generations. Romauli \& Fauzia [25] stated that organic agriculture is a farming activity that is friendly to the environment and tries to minimize negative impacts on the surrounding environment.

According to the Big Indonesian Dictionary (KBBI) innovation means the introduction or introduction of new things or updates. Innovation is something that is new, different from the existing or previously known ones. It can be in the form of ideas / ideas, methods, tools or improvements to new ways. Innovation is an idea, method, or object that is considered something new, but is not always the result of recent research. Innovation is something that can change habits. An innovation will be adopted by farmers if they have a good perception of the innovation [27]. Mardikanto in Aditiawati [27] states that innovation is an idea, information, behaviour, new products and practices that are not widely known, accepted and used, applied, and implemented by most people in a particular area. This can encourage change in all aspects of community life, for the realization of an improvement in the quality of life of each individual and farming community.

One such pathway to improving agricultural productivity depends on technology uptake and utilization [28]. Agricultural technology can be in the form of agricultural tools, cultivation techniques, production inputs, processing of production products, and so on. Organic farming technology aims to achieve higher output targets. Technology has an important role in changing a process to be of more economic value. Organic farming technology in this study focuses more on the process of cultivating organic rice. Organic farming technology based on technical guidelines for organic rice cultivation written by Surdianto \& Sutrisna [29] and issued by the West Java Agricultural Technology Research Institute (BPTP) includes: selection of seed varieties, land preparation, planting, use of seeds, fertilization, weeding, irrigation, pest control and harvesting. Basically, organic farming technology is not much different from intensified rice cultivation. The difference between the two lies in the choice of varieties, fertilizers and pesticides used.

At the decision stage, the individual decides to accept/reject adoption of the innovation [30]. Rogers [31] revealed that the adoption process consists of 5 stages, namely: the awareness stage, the interest stage, the evaluation stage, the trial stage, and the adoption stage. The process of adopting organic farming technology is actually a process of acceptance of innovation characterized by changes in behaviour, both in the form of knowledge, attitudes, and skills (psychomotoric) in farmers after receiving innovations delivered by extension agents. Meanwhile, the essence of the process of adopting organic farming technology is a mental process that occurs in farmers to make a decision to accept or reject the new technology. Rogers [31] argues that the process of making an innovation decision is a mental process in which a farmer goes through a series of stages, starting from knowing an innovation to making a decision to accept or reject and continue by confirming 
the decisions he has taken. A decision to implement this new idea requires different time dimensions from one farmer to another. This difference is caused by various reasons behind the farmers themselves, such as the condition of the farmers themselves, their environmental conditions and the characteristics of the new technology they have adopted [32]. According to Rogers [31] cited by Amala, et al, [33] there are a number of characteristics of innovation (which relate to the level of farmer adoption process of organic rice farming systems, namely: a) relative benefits (relative advantage), b) compatibility, c) complexity, d) possibility to be tried (triability), e) possibility to observe / feel the results (observability), f) age, g) education, h) farming experience, i) land area, j) number of dependents, k) cosmopolitan level, 1) participation rate, m) mass media channels, n) interpersonal channels.

\section{Methods}

This research is a qualitative research with descriptive methods. The research method is a scientific way to obtain data with specific purposes and uses [34]. The method used in this research is descriptive research method with a qualitative approach. Qualitative research places researchers as a key instrument, data collection techniques are carried out by combining and analysing inductive data [34]. Descriptive method which is a method used by collecting data in accordance with the actual data, then the data is compiled, processed, and analysed in order to provide an overview of the existing problems. A qualitative approach is used to obtain meaningful in-depth data. Meaning is the actual data, which is a value that is behind the visible data. The data is related to in-depth information about the process of adopting organic rice farming technology in the Sri Rejeki Farmer Group, Godean. The topics discussed were obtained from direct observation and in-depth interviews based on the question guide, until the data was saturated. In this research, the sampling method is descriptive qualitative. The respondents were taken purposively, this technique is intended to determine respondents who do understand some of the information required in the study [35]. The criteria for respondents in this study were 20 respondents consisting of management and members of farmer groups who are really involved in the application of organic rice farming technology.

\section{Results}

In most cases, agricultural technologies are introduced in pack ages that include several components, for example, High Yielding Varieties (HYV), fertilizers, and corresponding land preparation practices [36]. This study examines the process of adopting organic rice farming technology that occurs in the Sri Rejeki Farmer Group as stated by Rogers [31] which includes the awareness stage, the interest stage, the evaluation stage, the trial stage, and the adoption stage.

\subsection{Awareness Stage}

At the awareness stage, an individual becomes aware of the idea but lacks detailed information about it [37]. The awareness stage is the stage where the respondent first knows or realizes the existence of new organic farming technologies. Important things to know when first realizing about the existence of organic farming technology include where did rice farmers know about the existence of organic rice technology (source of information), when did farmers first find out (when they found out the information), what information did farmers get (known information), and how was the first reaction (initial reaction) knowing 
the existence of organic farming technology. The following is an explanation of the results of the study of the process of adopting organic farming technology in the Sri Rejeki Farmer Group at the awareness stage experienced by respondents from the Sri Rejeki Farmers Group, in Godean.

\subsubsection{Source and Time of Knowing Information}

Sources of information can influence farmers in deciding whether to adopt organic farming technology or not. Some recognize organic agriculture as being important for future global food security, whereas others project it to become irrelevant [38]. Farmers tend to accept or apply organic farming technology more quickly if they know the information related to organic farming technology from sources they trust. Smallholders will only adopt the technology they are aware of or have heard about it [39]. In addition, farmers will also find it easier to adopt an innovation if they see first-hand the results they will get later [28]. Furthermore, it is related to differences in the nature and character of individual farmers towards innovation, causing them to have different times to obtain this information. The time to know what is meant in this study is the time when the respondent first knew or knew about organic rice farming technology.

This study found that there was diversity in who the rice farmers in the Sri Rejeki farmer group received about organic farming technology. This study found that rice farmers obtained information about organic farming technology from various "sources", namely: the DIY Agriculture Office / experts, farmer groups, friends / relatives, and also the mass media (print and electronic). The findings regarding the "time to find information" for the first time about organic rice farming technology from respondents also varied, namely: long before field school (FS), sometime before FS, during the implementation of field school (FS), and sometime after field school (FS). More clearly, the description of the diversity of respondents based on the source and the time they first obtained information on organic farming technology is presented in table 1. Based on Table 1, it can be seen that there is a diversity of "sources of information" that respondents use when they first "know information" about the existence of organic farming technology. It turns out that when (when they got the information) the farmers first became aware of the existence of organic farming technology, they did not get it from all "information sources". This means that rice farmers in the Sri Rejeki farmer group get information on organic rice farming technology at a certain time, they get it through certain information sources as well. The more interesting thing is that respondents with certain individual characteristics are also doing it. In this study, it was found that farmers who knew for the first time about organic farming technology from printed and electronic mass media information sources, that is, he often reads the Sinar Tani newspaper and uses the internet. It turns out that the two rice farmers (10 percent) have similar individual characteristics, namely relatively high education (both high school graduates), accustomed to accessing information through mass media (newspapers and the internet), the two farmers have the category of "psychological characteristics" which relatively the same, namely "proactive" towards new things. Proactive means that farmers have the character to take their own initiative to seek new information about organic rice farming technology. They have known information about organic farming technology long before the implementation of the Field School by the DIY Agriculture Office. The two respondents knew information about organic farming technology through printed media (Sinar Tani agricultural newspaper) as well as news on the internet. Respondents who found out about this information via the internet stated that they had known about organic farming technology for a long time, around 2010, as he said:

"I opened it on the internet, right ...... back then, when I was still working at 
the office. At that time I read it on the internet. Yes, how to deal with rats, overcome pests, correct fertilization I read on the internet before there was a field school".

These respondents tend to be active in seeking information about organic farming technology. Meanwhile, the respondent who knew information through agricultural newspapers stated that he read information about organic farming technology for the first time in 2015.

Table 1. The diversity of respondents based on the source and time of knowing the information

\begin{tabular}{|c|l|c|l|c|c|c|}
\hline \multicolumn{7}{|c|}{ Resources } \\
\hline 1 & $\begin{array}{l}\text { Time Knows } \\
\text { No. }\end{array}$ & $\begin{array}{l}\text { Agrtment } \\
\text { of } \\
\text { /Experts }\end{array}$ \\
\hline & $\begin{array}{l}\text { fong before } \\
\text { (FS) }\end{array}$ & Farmers & $\begin{array}{c}\text { Friend/ } \\
\text { Relatives }\end{array}$ & $\begin{array}{c}\text { Media } \\
\text { Mass }\end{array}$ & $\begin{array}{c}\text { Diversity } \\
\text { time } \\
\text { knowing } \\
\text { information }\end{array}$ \\
\hline 2 & $\begin{array}{l}\text { Some time } \\
\text { field school } \\
\text { (FS) }\end{array}$ & $\begin{array}{l}\text { before field } \\
\text { school (FS) }\end{array}$ & $\sqrt{ }$ & & $\sqrt{ }$ & $\sqrt{ }$ \\
\hline 3 & $\begin{array}{l}\text { When it started } \\
\text { implementation } \\
\text { of field school } \\
\text { (FS) }\end{array}$ & $\sqrt{ }$ & & & & $\sqrt{ }$ \\
\hline 4 & $\begin{array}{l}\text { Some } \\
\text { time after } \\
\text { starting field } \\
\text { school (FS) }\end{array}$ & $\begin{array}{l}\text { Diversity of } \\
\text { information } \\
\text { sources }\end{array}$ & $\sqrt{ }$ & $\sqrt{ }$ & $\sqrt{ }$ & $\sqrt{ }$ \\
\hline
\end{tabular}

Furthermore, it was found that 10 farmers (50 percent) received information on organic farming technology from the Department of Agriculture. Two of the farmers (10 percent) received information "some time before the field school (FS)" (group chairman and secretary). The two respondents were Mr. Ngadiri and Mr. Sutarmin. They learned about the information about the organic farming technology when a representative from the DIY Agriculture Office visited to talk about the field school activities.

Meanwhile, 8 farmers (40 percent) received information on organic farming technology "during the implementation of FS" (active members), namely when field schools were held on organic farming technology from March to April 2017. The field school activities were carried out 6 times with a distance the time between one meetings to another meeting is approximately a week. As an illustration given by Mr. Darto Pawiro as one of the respondents who knew information on organic farming technology during the implementation of the FS:

"I know from the centre (DIY Agricultural Service) right at Mr. Dukuh's house (during field school), yes, the year 17 (2017). I only know from that 
centre".

In addition, there are still 4 farmers (20 percent) who get information on organic rice technology, whose source of information is from "farmer groups" who at the time got to know the information some time before FS. The four (4) respondents stated that they knew information about organic farming technology from the Sri Rejeki Farmer Group, from the explanation of the management. They obtained this information during a farmer group meeting which was held some time before the field school began. Namely, getting an explanation during a routine farmer group meeting some time before the field school was held.

The ten rice farmers who obtained their information from the "agricultural office" and the four rice farmers who obtained information from the "farmer groups" some time before the FS (70 percent of respondents), can be classified as having relatively the same "psychological characteristics" category, namely "responsive" . Responsive means that farmers have the character to respond quickly to the organic farming technology delivered by the agriculture agency or through farmer groups some time before FS. Incidentally, when the field school (FS) activity on organic farming technology was held, 16 (80 percent) respondents were full of rice farmers. Two respondents had "proactive" psychological characteristics and 14 respondents had "responsive" psychological characteristics. Furthermore, there were 4 farmers (20 percent) who joined to implement organic rice farming sometime after several field schools started running. The farmers who join to apply the organic rice technology are relatively less active than the other sixteen farmers. The four farmers believed the explanation of "friends / relatives" among members who happened to be relatively more active in group meetings regarding the advantages of organic farming. Then they joined the Field School. These four respondents can be categorized as farmers who have "adoptive" psychological characteristics. Adoptive means that farmers have the character of quickly accepting or adopting organic farming technology conveyed by "friends / relatives" of fellow farmer group members.

\subsubsection{Information That Is Known At The Conscious Stage}

The variety of information sources used by respondents to find out about organic farming technology can lead to a diversity of information that they receive which differs from one respondent to another. The more credible the sources of information that respondents use, the more reliable the information they get and can make respondents interested and interested in adopting organic farming technology. Table 2 reveals various information obtained by respondents regarding organic farming technology at the Sri Rejeki farmer group, in Godean. Based on table 1, it can be seen that in the early stages of farmers getting to know organic farming technology, there is a diversity of information obtained by farmers. Paddy farmers get complete information related to organic farming technology when they know "when the implementation of the field school (FS) started". Why is that, because at this time the experts / trainers from the DIY Agriculture Office conveyed all the material to be delivered during the implementation of the Field School on organic farming technology, including: organic rice planting systems, field management for organic rice requirements, pest control methods, use of natural ingredients as fertilizers and pesticides, as well as selecting superior seeds. So the early stages of rice realized that there was information about organic farming technology, rice farmers knew that later what would be explained during the field school was related to this material. Even though you don't know the content in detail, but the farmer already has an idea of what he will know and what he will practice during the field school implementation. Through the explanation at the beginning of the field school implementation, there was confidence in the farmers that technically they could master organic farming technology through field schools. 
Tabel 2. Information obtained by respondents based on information sources

\begin{tabular}{|c|c|c|c|}
\hline No. & $\begin{array}{c}\text { Source } \\
\text { Information }\end{array}$ & Time Knows & Information Obtained \\
\hline \multirow[b]{2}{*}{1} & \multirow[b]{2}{*}{$\begin{array}{l}\text { DIY } \\
\text { Agricultural } \\
\text { Service }\end{array}$} & $\begin{array}{l}\text { Some time before } \\
\text { FS }\end{array}$ & $\begin{array}{l}\text { - Organic rice technology is easy to do } \\
\text { - Profitable } \\
\text { - Environmentally friendly } \\
\text { - Healthy }\end{array}$ \\
\hline & & $\begin{array}{l}\text { When it started } \\
\text { implementation of } \\
\text { FS }\end{array}$ & $\begin{array}{l}\text { - Organic rice planting system } \\
\text { - Field management for organic rice } \\
\text { requirements } \\
\text { - How to control pests } \\
\text { - Use of natural ingredients as fertilizers } \\
\text { and pesticides } \\
\text { - Selection of superior seeds }\end{array}$ \\
\hline 2 & Farmer group & Sometime before FS & $\begin{array}{l}\text { - Profitable } \\
\text { - } 1000 \text { organic village program } \\
\text { - Organic rice field requirements } \\
\text { - Organic certification }\end{array}$ \\
\hline \multirow[t]{2}{*}{3} & \multirow{2}{*}{$\begin{array}{l}\text { Friends / } \\
\text { relatives }\end{array}$} & $\begin{array}{l}\text { Some after starting } \\
\text { FS }\end{array}$ & - Cultivation of organic agriculture \\
\hline & & After starting FS & - The benefits that will be obtained \\
\hline 4 & Media & Long before FS & $\begin{array}{l}\text { - } 1000 \text { organic village program } \\
\text { - The benefits of applying organic } \\
\text { agricultural technology for the } \\
\text { environment and health } \\
\text { - Benefits and opportunities obtained } \\
\text { through the application of agriculture }\end{array}$ \\
\hline
\end{tabular}

Farmers who received information on organic farming technology some time before the field school from the DIY Agriculture Service were group managers, namely the chairman and secretary of the Sri Rejeki farmer group. Since those who conveyed were a reliable formal source of information (DIY Agricultural Service) and the position of farmers as group administrators, there is no reason not to believe it. The Department of Agriculture, through its experts, conveyed the basic things about organic farming technology. Experts from the DIY Agricultural Service easily conveyed communication messages effectively. Organic rice farming technology is technically easy to implement, profitable, healthy and environmentally friendly. The effectiveness of transferred technology has a major impact on small businesses' competitiveness and access to markets [40].

The printed mass media, especially the Sinar tani newspaper and the internet, have high credibility as a source of agricultural information. Respondents who received information through the Sinar Tani newspaper received knowledge regarding the advantages and opportunities in cultivating organic farming. Respondents who know information on organic farming technology through news from the internet get information about the 1000 organic villages program by the Ministry of Agriculture which proclaims a sustainable life and healthy lifestyle for themselves and for the environment. There has been effective communication with respondents who received initial information about organic rice technology from the mass media (Sinar Tani newspaper and the internet). On the other hand, farmers who access mass media are also used to accessing information from both media. Farmers can judge correct information or just hoaxes. Furthermore, the strength of information sources from friends / relatives lies in the extent to which they have built "relationships" in their social interactions. If a friend or brotherhood that has been built so 
far shows a trusting social relationship, friends / relatives can also be seen as having a high level of trust as a source of information. Although perhaps the information he conveyed was incomplete or incomplete. The trust that causes someone to follow a friend / relative's invitation does not lie in the content. Friendship / kinship is a form of interpersonal communication. Which in this communication emphasizes relationship more than content. Furthermore, the strength of information sources from friends / relatives lies in the extent to which they have built "relationships" in their social interactions. If a friend or brotherhood that has been built so far shows a mutual trusting social relationship, then friends / relatives can also be seen as having a high level of trust as a source of information. Although perhaps the information he conveyed was incomplete or incomplete. The trust that causes someone to follow a friend / relative's invitation does not lie in the content. Friendship / kinship is a form of interpersonal communication. Which in this communication emphasizes relationship more than content. Furthermore, the strength of information sources from friends / relatives lies in the extent to which they have built "relationships" in their social interactions. If a friend or brotherhood that has been built so far shows a mutual trusting social relationship, then friends / relatives can also be seen as having a high level of trust as a source of information. Although perhaps the information he conveyed was incomplete or incomplete. The trust that causes someone to follow a friend / relative's invitation does not lie in the content. Friendship / kinship is a form of interpersonal communication. Which in this communication emphasizes relationship more than content. Then friends / relatives can also be seen as having a high level of trust as a source of information. Although perhaps the information he conveyed was incomplete or incomplete. The trust that causes someone to follow a friend / relative's invitation does not lie in the content. Friendship / kinship is a form of interpersonal communication. Which in this communication emphasizes relationship more than content. Then friends / relatives can also be seen as having a high level of trust as a source of information. Although perhaps the information he conveyed was incomplete or incomplete. The trust that causes someone to follow a friend / relative's invitation does not lie in the content. Friendship / kinship is a form of interpersonal communication. Which in this communication emphasizes relationship more than content.

Furthermore, respondents who know the information through the farmer group, if it is related to profits, will become a collective strength to achieve it. In the application of organic farming technology, such as the selling price of organic rice which is higher than ordinary rice, it can also be a special attraction. A farmer group, when it comes to discussing the economic benefits they will get, usually becomes a strong motivation. Moreover, there are other advantages, such as being healthy and environmentally friendly. The respondents who expressed interest from the start that they received information about organic farming technology were mostly because they knew what advantages and disadvantages they would get when applying organic farming technology. Especially those who know information about organic farming technology through field school activities held by the DIY Agriculture Service, they tend to be interested in trying it because they know that they will receive free fertilizer when trying to apply the organic farming technology. They think, there is nothing wrong with trying because at least the costs they spend are not as much as they used to if they get subsidies (free).

In addition, there were respondents who were interested in knowing the information from the start because they knew that the production results produced after applying organic farming technology were healthier than the usual production results when consumed. They want to provide healthier and better quality food to their families. The respondent also acknowledged that rice produced from organic farming was tastier and fluffier. The following is the expression of Mr. Agus Waluyo when asked about his reaction or interest in applying organic farming technology: 


\begin{abstract}
"I'm interested, the problem is I consume it myself, the results are for myself" said Mr. Agus Waluyo when asked how he reacted when he first learned about organic farming technology. I think the organic program is good, it's just that for now there are many farmers who are old and think that if you don't use chemicals it won't affect the plants."
\end{abstract}

Meanwhile, farmers whose initial response were not interested in adopting it when they knew information about organic farming technology, it could be because the sources of information they had were not able to convince them to try to apply organic farming technology. They only listen to information about organic farming technology at a glance through chatting with friends. The age that is no longer young is also one of the reasons respondents are not too interested in the organic agricultural technology innovation that is present in their midst. One of the changes they must make when they want to implement organic farming is the fertilization process. If usually they just spray the fertilizer using a sprayer, so when switching to organic farming technology they have to fertilize manually and with more intensity than when using chemical fertilizers. This is what Puji Mulyono's grandfather said:

"I am not strong anymore if I am told to go back and forth to give fertilizer to the fields. If you want to pay other workers, where do you get the money? "

Respondents who were no longer young felt objected to the changes they had to make. Their age which is no longer young causes the energy they have to no longer be limited when they are young. If they insist on trying to implement organic farming, then they need additional manpower to do some of the things they are no longer able to do on their own. Meanwhile, to increase the workforce, they need to increase the cost of expenses to pay for the labour services they use. The additional cost is also one of the things that causes them to be slightly objected and not interested in applying organic farming technology.

\title{
3.1.3 Initial Reaction
}

The initial reaction referred to is the reaction given by the first respondent after receiving information related to organic farming technology from various sources during the awareness stage. In this study, it was found that the initial reactions of respondents were "interested" and "not interested." The initial reactions that respondents had could affect the subsequent process in adopting organic farming technology. If respondents are not interested in the information they get, then the subsequent adoption process is likely to be more difficult and slower than the adoption process that will occur for respondents who have been interested in the organic farming technology from the start. The findings of this study indicate that at this stage of awareness, respondents generally expressed their interest in organic farming technology.

The respondents who expressed their interest from the start in receiving information about organic farming technology were mostly because they knew what advantages and disadvantages they would get when applying organic farming technology. Especially those who know information about organic farming technology through field school activities held by the DIY Agriculture Service, they tend to be interested in trying it because they know that they will receive free fertilizer when trying to apply the organic farming technology. They think, there is nothing wrong with trying because at least they don't have to pay for the field school because they get subsidies (free).

In addition, respondents who were interested from the start in knowing this information were also due to knowing that the production results produced after applying organic farming technology are healthier than the usual production results when consumed. They 
want to provide healthier and better quality food to their families. The respondent also acknowledged that rice produced from organic farming was tastier and fluffier. The following is the expression of Mr. Agus Waluyo when asked about his reaction or interest in applying organic farming technology:

"I'm interested, the problem is I consume it myself, the results are for myself" said Mr. Agus Waluyo when asked how he reacted when he first learned about organic farming technology. I think the organic program is good, it's just that for now there are many farmers who are old and think that if you don't use chemicals it won't affect the plants."

Meanwhile, farmers whose initial reactions were not interested in adopting it when they found out about information about organic farming technology, it could be because the sources of information they had were not able to convince them to try to apply organic farming technology. They only listen to information about organic farming technology at a glance through chatting with friends. The age that is no longer young is also one of the reasons respondents are not too interested in the organic agricultural technology innovation that is present in their midst. One of the changes they must make when they want to implement organic farming is the fertilization process. If usually they just spray the fertilizer using a sprayer, So when switching to organic farming technology they have to fertilize manually and with more intensity than when using chemical fertilizers. This is what Puji Mulyono's grandfather said:

"I am not strong anymore if I am told to go back and forth to give fertilizer to the fields. If you want to pay other workers, where do you get the money? "

Respondents who were no longer young felt objected to the changes they had to make. Their age which is no longer young causes the energy they have to no longer be as strong as when they were young. If they insist on trying to implement organic farming, then they need additional manpower to do some of the things they are no longer able to do on their own. Meanwhile, to increase the workforce, they need to increase the cost of expenses to pay for the labour services they use. The additional cost is also one of the things that caused them to be slightly objected and not interested in applying organic farming technology. This is in accordance with Soekatawi's [32] expression which states that someone will usually act more carefully to adopt a technological innovation if the process of adopting this innovation involves greater costs. Additional information about the details of the initial response of respondents after knowing the information on organic farming technology for the first time is shown in table 3.

Table 3. Respondents' initial reactions based on information sources

\begin{tabular}{|c|c|c|c|c|c|}
\hline \multirow[b]{2}{*}{ No. } & \multirow[b]{2}{*}{ Resources } & \multicolumn{2}{|c|}{ Reaction Early } & \multirow{2}{*}{$\begin{array}{c}\text { Number } \\
\text { (soul) }\end{array}$} & \multirow{2}{*}{$\begin{array}{c}\text { Percentage } \\
(\%)\end{array}$} \\
\hline & & Interested & $\begin{array}{c}\text { Not } \\
\text { interested }\end{array}$ & & \\
\hline 1 & $\begin{array}{l}\text { DIY } \\
\text { Agricultural } \\
\text { Service }\end{array}$ & 10 & & 10 & 50 \\
\hline 2 & Farmer group & 2 & 2 & 4 & 20 \\
\hline 3 & $\begin{array}{l}\text { Friends / } \\
\text { relatives }\end{array}$ & 2 & 2 & 4 & 20 \\
\hline 4 & Media & 2 & & 2 & 10 \\
\hline \multicolumn{2}{|c|}{ Number (soul) } & 16 & 4 & 20 & \\
\hline \multicolumn{2}{|c|}{ Percentage (\%) } & 80 & 20 & & 100 \\
\hline
\end{tabular}

When seen from Table 3, it can be concluded that most respondents have been 
interested in organic farming technology since they first learned about this information. Of the 20 respondents who were asked, only 4 people (20 percent) said they were not interested in organic farming technology after receiving this information. The thing to be grateful for from the findings of this study is that farmers whose initial reactions were not interested did not have the effect of stopping the adoption process.

\subsection{The Interested Stage}

At this stage the farmers began to look for additional information to complement the information they had previously obtained. As in the awareness stage, at this stage additional information is also obtained from various sources of information. Respondents obtained information about organic rice farming technology from print and electronic media, friends and relatives, as well as from farmer groups as well as experts (from provincial and district agriculture offices) in the field of agriculture. In this stage, farmers seek reinforcement to make decisions whether they will apply this organic farming technology in the future or not. At this stage, farmers have their own perceptions of organic rice technology. The following is a further explanation regarding the 'interest' stage that occurs in respondents.

\subsubsection{Additional Sources of Information}

At this stage farmers are looking for additional information related to organic farming technology to strengthen their self-confidence. As previously stated, the sources of information used by farmers are exactly the same as in the previous stage (awareness stage), namely: the DIY Agriculture Office, printed / electronic media, farmer groups, and friends / relatives. The information obtained by farmers at this "interested" stage can influence farmers' decisions whether they will continue to the next process or not. Sources of information in obtaining additional information on organic rice technology are relatively evenly distributed. Sources of information are used by respondents relatively evenly, ranging from 15 percent to 35 percent. The interesting thing is that many farmers are looking for additional information on organic rice technology from friends / relatives. This happens because the person closest to the farmer's daily life (after the completion of the field school activities) is a friend or relative who also happens to be his close neighbour. This is where they share information about organic rice technology. Respondents exchanged experiences with their friends who also applied organic farming technology. They are more comfortable looking for information and asking questions about organic farming information technology through their friends because they feel closer to their fellow farmers, so that the conversation between them is more comfortable and smooth. They did not feel awkward to ask their friends. This happens because the person closest to the farmer's daily life (after the completion of the field school activities) is a friend or relative who also happens to be his close neighbour. This is where they share information about organic rice technology. Respondents exchanged experiences with their friends who also applied organic farming technology. They are more comfortable looking for information and asking questions about organic farming information technology through their friends because they feel closer to their fellow farmers, so that the conversation between them is more comfortable and smooth. They did not feel awkward to ask their friends. This happens because the person closest to the farmer's daily life (after the completion of the field school activities) is a friend or relative who also happens to be his close neighbour. This is where they share information about organic rice technology. Respondents exchanged experiences with their friends who also applied organic farming 
technology. They are more comfortable looking for information and asking questions about organic farming information technology through their friends because they feel closer to their fellow farmers, so that the conversation between them is more comfortable and smooth. They did not feel awkward to ask their friends.

Numerous studies have indicated that important factors of the decision to adopt organic farming include the amount of training provided [41]. Farmer training, demonstration, and farmer-to-farmer interactions were perceived as the most effective agricultural extension methods [42]. In fact, the least information source from farmer groups is used by farmers to seek additional information. Farmers can use Android to connect with the agricultural service / experts or open the internet to find additional information. Another thing that is interesting is when at the awareness stage some farmers have an initial response that is not interested, it turns out that at the next stage (the interest stage) these farmers continue to seek additional information about organic rice technology. The detailed sources of information used by respondents in strengthening their belief in adopting organic farming technology are presented in Table 4.

Table 4. Distribution of respondents based on additional sources of information

\begin{tabular}{|c|l|c|c|}
\hline No. & \multicolumn{1}{|c|}{ Resources } & $\begin{array}{c}\text { Number } \\
(\mathbf{s o u l})\end{array}$ & $\begin{array}{c}\text { Percentage } \\
(\boldsymbol{\%})\end{array}$ \\
\hline 1 & Friends or relatives & 7 & 35 \\
\hline 2 & DIY Agriculture Service / experts & 6 & 30 \\
\hline 3 & Print / electronic media & 4 & 20 \\
\hline 4 & Farmer group & 3 & 15 \\
\hline & \multicolumn{1}{|c|}{ total } & 20 & 100 \\
\hline
\end{tabular}

Based on table 4, it can be seen that the respondents who sought additional information through the Department of Agriculture or agricultural experts were 6 respondents (30 percent). Respondents who fall into this category tend to have "cosmopolitan" sociological characteristics. These respondents have relatively higher physical mobility, and have psychological characteristics that are open and willing to interact with parties outside their social system. Respondents felt that they used to communicate with the agricultural office or experts to further strengthen their beliefs regarding organic rice technology. They have a high curiosity. Respondents who fall into this category also tend to have higher social awareness than other farmers. Meanwhile, 4 other respondents stated that they seek additional information through books, magazines, news and articles that they have or get from the internet. Respondents seek out information that is consistent with the information they previously had to convince themselves to adopt organic farming technology. This is in line with what Soekartawi [32] stated that farmers will start to collect information from various parties, both from print media and friends and also experts in the field of agriculture to develop the information they already have in generating their interest in applying or adopt an innovation. Respondents seek out information that is consistent with the information they previously had to convince themselves to adopt organic farming technology. This is in line with what Soekartawi 32] stated that farmers will start to collect information from various parties, both from print media and friends and also experts in the field of agriculture to develop the information they already have in generating their interest in applying or adopt an innovation. Respondents seek out information that is consistent with the information they previously had to convince themselves to adopt organic farming technology. This is in line with what Soekartawi [32] stated that farmers will start to collect information from various parties, both from print media and friends and also experts in the field of agriculture to develop the information they already have in generating their interest in applying or adopt an innovation. 


\subsubsection{Respondents' Reactions at the Interested Stage}

After the respondents collect various additional information they need from various sources related to organic farming technology, there may be other reactions that are different from the initial reaction (in the awareness stage). The findings of the study show that initially there were 16 farmers who initially reacted, increased to 18 farmers, and from 4 farmers who were not interested, it turned out that there were no farmers who were not interested. It can be seen that the more farmers learn about organic farming, the less interested they become. After getting additional information related to organic farming technology, there were still 2 respondents who were still hesitant to apply this technology. The age factor becomes one of the barriers for them to apply this technology. Both respondents have entered an age that is no longer productive for work. In addition, the factor of land ownership is also the cause of their doubts about applying organic farming technology. The land they currently manage is production sharing, where they only work as cultivators of the land and cannot make full decisions on the land they cultivate. In addition to detailed information related to respondents' reactions at the interested stage after receiving various additional information about organic farming technology, table 5 is presented. Where they only work as cultivators of the land and cannot make full decisions on the land they cultivate. In addition to detailed information related to respondents' reactions at the interested stage after receiving various additional information about organic farming technology, table 5 is presented. Where they only work as cultivators of the land and cannot make full decisions on the land they cultivate. In addition to detailed information related to respondents' reactions at the interest stage after receiving various additional information about organic farming technology, table 5 is presented.

Table 5. Respondents' reactions at the interested stage

\begin{tabular}{|c|l|c|c|}
\hline No. & Reaction & Number (soul) & Percentage (\%) \\
\hline 1 & Interested & 18 & 90 \\
\hline 2 & Doubt & 2 & 10 \\
\hline 3 & Not interested & 0 & 0 \\
\hline & total & 20 & 100 \\
\hline
\end{tabular}

Based on Table 5, it can be seen that more and more respondents are interested and convinced to apply organic farming technology after they get additional information related to this technology. As many as 90 percent (or 18 of 20) respondents said they wanted to try applying organic farming technology after obtaining various additional information. Especially after getting an explanation regarding the relative benefits they will get after implementing organic rice technology.

\subsection{Evaluation Stage}

After collecting the additional information they needed to convince themselves of adopting organic farming technology, the respondents began to enter the evaluation stage in the process of adopting organic rice technology. It is at this stage that the respondent begins to further consider whether the interest that has arisen after gathering additional information should be continued or not. At this stage the respondents begin to seriously assess and consider the situation and circumstances they have, both in terms of ability, capital, and also the risks they will face. They consider adopting organic farming technology from various aspects, both from a technical, economic and also from a social perspective. The result of research by Md Sikandar Azam and Musarrat Shaheen shows that marketing factors and government policies have a significant effect on adoption of organic farming [43]. 


\subsubsection{Respondents' Considerations In Adopting Organic FarmingTecnology}

\section{1) The Benefits You Get}

A technology adoption process will occur more quickly if the new technology to be adopted provides greater benefits than the old technology it replaces [32]. At the evaluation stage, respondents stated that they were more confident about adopting organic rice technology after knowing the benefits they would get by applying this technology. There are several advantages that were considered by respondents in adopting organic farming technology. One of these advantages is the higher selling price of organic rice compared to rice in general. Gapoktan is also willing to buy organic rice harvested from farmers' land at a higher price. If usually the rice they harvest is bought at a price of IDR 400,000 per quintal, So Gapoktan is willing to buy organic rice they harvest at a price of IDR 500,000 per quintile. The large price difference makes respondents more interested in applying organic farming technology. Pak Sutarmin revealed:

"Earlier, the chairman (Mr. Ngadiri) talked with Mr. Bangun (the Gapoktan party), the organic one is wet grain, Gapoktan wants to buy 500 (thousand) 1 quintillion. If the non-organic ones are 400 (thousand) wet unhulled rice, the price is also 400 and 500 . The difference is 100 thousand."

Apart from that, the impact of organic farming on health was also a consideration for respondents to apply organic farming technology. By applying organic farming technology, farmers have indirectly tried to restore the purity of the soil, the land they cultivate will become more loose and fertile. Besides, the production and consumption of organic products are possible if most farmers have enough knowledge or are aware of the effect of conventional farming on the environment [44]. Production results obtained from the application of organic farming technology are also healthier for consumption than those that have not implemented organic farming. Because organic rice does not contain chemicals. Mr. Agus Waluyo revealed one of the things he considered when applying organic farming technology, namely:

"If consumed, the human body will be better, healthier. Make body condition better. Soil purity also returned well. If organic products don't contain much glucose which contains chemicals, I think health is the main thing. "

\section{2) Compatibility}

Compatibility is the extent to which new technologies are suitable for farmers. Compatibility can be defined as the extent to which the new technology is suitable and in accordance with the farmer's ability. The application of organic rice technology is essentially the same and technically does not differ much from conventional rice. The first thing that distinguishes only the use of organic matter for fertilizers. The difference felt by respondents when adapting to apply organic farming technology was during the fertilization process. The fertilization process when applying organic farming technology must use natural ingredients derived from nature. The respondents were taught how to make fertilizer from cow dung because it happened that some of the residents around them had small-scale cattle farms.

Then the difference between the applications of organic farming technology with conventional farming also lies in how to deal with pests and diseases that attack plants. Pest and disease control in organic agricultural technology must use materials that also come from nature. One of the ingredients used by respondents in dealing with pests is the fruit of 
the simpalak. Simpalak fruit is used by farmers to repel rats in the field. The use of simpalak fruit to repel rat pests is very easy, that is, by placing it on the ground, the rats will avoid it. This method is very easy for farmers to implement. In addition, respondents also used to use pace fruit or more commonly known as noni fruit to repel rats.

The irrigation water is avoided from chemical substances. The respondent has certain requirements for using water to irrigate organic rice fields. Water that will flow into organic rice fields must first undergo a filtering process. Therefore, the Sri Rejeki Farmers Group created a small storage pool that functions to collect water from the small river flow around their rice fields before flowing into the land area. In the small storage pool, water hyacinth plants are given which function to filter out the chemical substances contained in the river water, so that the water that will flow to the rice fields will be free of chemicals. Likewise, do not use genetically modified seeds that involve the use of chemicals in the process. So substantively, organic rice cultivation and conventional rice cultivation are substantially the same. However, for some (2) respondents who were no longer young, this was the reason they felt a little objection to applying organic farming technology.

\section{3) Complexity}

The complexity referred to in this study is the level of complexity faced by farmers when they apply organic farming technology. The level of ease of an innovation has a significant effect on the speed with which farmers accept the innovation. The process of adopting innovation will be faster if the innovation is easy to put into practice. The findings in this study indicate that in general the respondents did not find it difficult to implement organic rice cultivation. They feel that the application of organic farming technology is not much different from conventional agricultural technology, from the process of preparing seeds to harvesting. The difference between the two technologies is not too big, causing organic farming technology to be accepted by respondents in the Sri Rejeki Farmer Group.

\section{4) Triability}

A technology will be easily adopted if the technology is easily tried by farmers. The existence of field schools gives respondents the opportunity to practice and try organic farming technology directly on their land. During the span of the field school implementation, respondents tried to apply organic farming technology on a small scale on their own land. During the field school, the farmers are accompanied by a team from the agriculture department to supervise and assist them in the application of organic farming technology.

\section{5) Observability}

The process of adopting an innovation will occur faster if the results of the technological innovation are easily observed by others. Farmers will be more interested in applying organic farming technology if they have seen real examples of the success and benefits that will be obtained after applying the technology. Prior to the implementation of the field school, the Sri Rejeki farmer group visited the Pakem area, Sleman, which is one of the demonstration areas for organic farming in Yogyakarta. The visit by the Sri Rejeki Farmer Group was conducted to motivate farmers to apply organic farming technology. During this visit the farmers were invited to have a look around while discussing organic farming technology that has been applied in Pakem. 


\subsubsection{The Time It Take Respondent In The Evaluation Process}

Every person has different abilities to accept something new in his life, so the time it takes for someone to accept new things such as innovation or new technology in his life is also different. In the evaluation process, the farmer will further consider whether he will continue his interest after gathering additional information or not. If farmers are interested, they will try to apply the new technology. The following is the time it takes respondents at the evaluation stage in the process of adopting organic farming technology.

Table 6. Time needed by respondents in the evaluation stage

\begin{tabular}{|c|c|c|c|}
\hline No. & Time required & Number (soul) & Percentage (\%) \\
\hline 1 & $<1$ month & 10 & 50 \\
\hline 2 & $1-3$ months & 7 & 35 \\
\hline 3 & $>3$ months & 3 & 15 \\
\hline & total & 20 & 100 \\
\hline
\end{tabular}

Based on table 6 , it can be seen that as many as $50 \%$ of respondents are in the group of people who are fast in making decisions, they only need less than 1 month to consider that they will try to apply organic farming technology. A total of 7 respondents said that it took them about 1-3 months to consider whether they would try to apply organic farming technology or not. There are some people in this group who want to wait and see the results of the organic farming technology that is being implemented by some of their fellow farmers.

In addition, there were 3 respondents who needed a long time ( 5 months) at the evaluation stage in the process of adopting this organic farming technology. Respondents who fall into this group tend to be older. They are also a little difficult to accept the changes that occur around them, so the time it takes for these respondents to consider whether they will try to apply this organic farming technology or not can also be said to be longer than other respondents.

The final result of this evaluation phase is to decide whether farmers are willing to try organic agricultural technology innovations or not. Renewed interest in organic agriculture is mainly due to two concerns, falling agricultural yield in certain areas as a result of inter alia excessive use of chemical inputs, decreased soil fertility and environmental awareness [45]. In this study, the final results of the evaluation phase experienced by all respondents stated that they were willing to try to apply organic farming technology on a small scale on their land even though the time needed by each respondent in deciding to try this technology was not the same.

\subsection{Try Stage}

The trial stage is the stage where the respondent starts doing what he has decided earlier in the evaluation stage. At this stage the respondents began to slowly try to apply organic farming technology to their lives. They do this experiment on the small land they have. However, in this study, most respondents immediately tried to apply it to most of their land. The following is the area of land used by respondents in this experimental stage

Table 7. The area of land used by respondents in the experimental stage

\begin{tabular}{|c|c|c|c|}
\hline No. & Experimental land area (m2) & Number (soul) & Percentage (\%) \\
\hline 1 & $500-1,500$ & 9 & 45 \\
\hline 2 & $>1,500-3,000$ & 10 & 50 \\
\hline 3 & $>3,000$ & 1 & 5 \\
\hline & total & 20 & 100 \\
\hline
\end{tabular}


The most obvious treatment is to reduce the use of chemicals in the rice cultivation process. The process of reducing chemicals such as fertilizers and pesticides is not done all at once. This reduction is done in stages. They try to reduce the use of chemicals by as much as $25 \%$ and replace them with organic materials that come from nature around them. Then during the next planting period they reduce the use of chemical fertilizers and pesticides again, so that the ratio between chemical and organic is 50:50. They continue to do this reduction until they actually use organic matter without the slightest chemical mixture during the planting process until harvest.

"At that time I tried $500(\mathrm{~m} 2)$ first, it was still mixed with chemicals. Use 1 bucket of urea to stimulate growth at the age of 1 week. I drive using 1 bucket for $500 \mathrm{~m} 2$. It looks very little, but the cow dung is more, "said Mr. Agus Waluyo when trying to apply organic farming technology."

During this trial period, only a few farmers experienced a few obstacles, especially those who were no longer young. The fertilization process that has to be done repeatedly and manually makes them expend more energy than usual. In addition, the weed control process that must be done manually is also quite draining for those who are no longer productive.

\subsection{Adoption Stage}

It is at this stage that farmers decide that the information they have gathered and the experiments they have conducted are sufficient to apply organic farming technologies to their land on a wider scale. The adoption stage itself does not stop when respondents have adopted organic agricultural technology innovations. Farmers or respondents who initially accept organic agricultural technology innovation have the possibility to stop and return to conventional agricultural technology at a later date. Likewise, Soekartawi [32] describes the paradigm of adoption of innovation by individuals who initially refuse to implement innovation, then later apply the technological innovation.

In this study, all respondents accepted to apply organic farming technology at the beginning of the time after the field school was held, so the next possibility is that there are only 2 choices. First, they continue to apply organic farming onwards and second, those who stop applying organic farming technology (return to conventional farming). Following are the number of respondents who continue or stop implementing organic farming technology:

Table 8. Distribution of respondents based on consistency in the application of organic farming technology

\begin{tabular}{|c|l|c|c|}
\hline No. & Respondent Consistency & $\begin{array}{c}\text { Number } \\
\text { (soul) }\end{array}$ & $\begin{array}{c}\text { Percentage } \\
(\mathbf{\%})\end{array}$ \\
\hline 1 & Adopters that continue adoption & 16 & 80 \\
\hline 2 & Adopters that stopped adopting & 4 & 20 \\
\hline \multicolumn{2}{|c|}{ total } & 20 & 100 \\
\hline
\end{tabular}

Based on table 8 , it can be seen that most of the respondents have decided to continue implementing organic farming technology. Those who are consistent and decide to continue applying organic farming technology feel the benefits they can get while implementing this technology. In addition to the higher selling price of organic rice when sold to Gapoktan, health reasons are also one of their considerations to keep applying this organic farming technology. Respondents who use health as their reason for continuing to apply organic farming technology want to provide the best quality food for their families. 
"Now, only $500(\mathrm{~m} 2)$ of organic ones are available, I bring them home to eat at home. The problem is that for eating myself I try to be good and healthy. If it is non-organic, I will sell it," said Mr. Hariyadi.

Some respondents who decided to continue implementing organic farming, some only apply this technology to a small portion of their land. They only work as tenant farmers, so they only apply the organic farming technology to the small land they have.

Most land owners do not really pay attention to or give priority to the technology used in the land. They are only concerned with the income they get. Meanwhile, most of the sales process of the crops found in Brongkol is carried out using the slash system. In the slash system, the slasher do not differentiate between organic and non-organic rice. The loggers only count the area of land they cut and the amount of weight of rice they get. With such a system, landowners do not place too much importance on organic farming technology as the technology they must apply to their land.

In addition, there were 4 respondents who initially decided to apply organic farming technology then decided to stop and return to applying conventional agricultural technology. The four respondent farmers are included in the respondents who are no longer young. The reason they stopped applying agricultural technology was because the energy they had no longer supported them to carry out regular fertilization with organic fertilizers. Another reason why they no longer apply organic farming technology is because the land they own can also be said to be quite extensive, so they feel they are unable to manage their land organically. The farmers may be aware of the benefits of going organic but what matters most is the attitude and preparedness of farmers to convert to organic farming [46].

\section{Conclusion}

The results of the study found that the "awareness stage" had a variety of sources of information from the agriculture agency, farmer groups, friends / relatives and print / electronic media and time variations. Respondents are familiar with information on organic farming technology some were long before FS, sometime before FS, during the implementation of field school (FS), and there were farmers who got to know some time after field school. There is a variety of "known information" respondents from the various sources of information they use, and generally respondents have an initial "interested" reaction. On "interest stage", respondents seek additional information from various information sources, and generally respondents have a "interested reaction". In the "evaluation stage", respondents have various considerations before accepting organic rice technology (considerations: advantages, compatibility, complexity, triability, and observability of organic rice technology) and each farmer takes different times in the evaluation process. In the "trial phase", respondents applied their respective fields of various sizes, generally between 500 square meters to 300 square meters. Meanwhile, at the "adoption stage", generally respondents accepted the application of organic rice technology, and only a small proportion did not continue the adoption. It is important to carry out intensive counselling aimed at young farmers.

\section{References}

1. M. Mwangi and S. Kariuki, J. Econ. Sustain. Dev. 6, 208 (2015).

2. Dutta, A. (2019). Organic Agriculture: a Pathway for Achieving Economic and Environmental Sustainability in North-East India. EPRA International Journal 
of Research and Development (IJRD), Volume 4, 57.

3. David, A., Ahmed, R. R., Ganeshkumar, C., \& Sankar, J. G. (2020). Consumer Purchasing Process of Organic Food Product an Empiral Analysis. ResearchGate, Volume 21, no 177, 129.

4. Adebanjo, H.A, M., \& E.O.S, B. (2020). Determinants of Organic Farming Adoption Among Rural Farmers in Epe Local Goeverment Area, Lagos State, Negeria. International Journal of Agriculture and Rural Development, Volume 23(1): 4978-4985.

5. N. . R.N, T. . Hapsari, and E. . Kuntadi, J. Ekon. Pertan. Dan Agribisnis (2018).

6. Ferdous, Z., Zulfiqar, F., Hasan, A. K., \& Datta, A. (2020). Potential and challenges of organic agriculture in Bangladesh: a review. Journal of Crop Improvement.

7. Etim, N.-A. A., \& Udoh, E. J. (2020). Adoption of organic waterleaf farming for sustainable food production in Akwa Ibom State, Nigeria. International Journal of Development and Sustainability, Volume 9, 1-13.

8. Das, S., Chatterjee, A., \& Pal, T. K. (2020). Organic Farming in India: a Vision Towards a Healthy Nation. Food Quality and Safety, Volume 4, 69-76.

9. T. C. Mendoza, J. Sustain. Agric. 24, 1 (2016).

10. S. Jahroh, Cirad-Inra-SupAgro (2010).

11. Y. K. Lestari and A. T. Suryana, Sustain. Org. Rice Farming Indones. 55 (2013).

12. J. Sharifuddin and M. Z. Abidin, Forum Penelit. Agro Ekon. 35, 45 (2018).

13. Ashari, J. Sharifuddin, Z. A. Mohammed, and R. Terano, J. Agro Ekon. 34, 35 (2016).

14. Naika, R., Sivapragasam, C., \& Patoju, S. S. (2020). Impact of Organic Farming on Sistainable Livelihood of Farmers. Building Sustainable Communities, 361-375.

15. Ashari, Sharifuddin, J., Mohammed, Z., \& Terano, R. (2018). Paddy farmer's perception and factors influencing attitude and intention on adoption of organic rice farming. International Food Research Journal, Vol. 25, 135-145.

16. T. Dagos, R. A. (2019). Assessment of Lowland Rice-based Organic Farming in Selected Municipalities of Occidental Mindoro, Philippines. International Journal of Agriculture System, Volume 7. 2580-6815.

17. G. E. Mwalupaso, M. Korotoumou, A. M. Eshetie, J. P. Essiagnon Alavo, and X. Tian, J. Clean. Prod. 232, 639 (2019).

18. 12. L. O. Bello, L. J. S. Baiyegunhi, and G. Danso-Abbeam, Econ. Innov. New Technol. 1 (2020).

19. 14. I. W. Budiasa, Asian J. Agric. Dev. (2014).

20. Janjhua, Y., Chaudhary, R., Mehta, P., \& Kumar, K. (2019). Determinants of Farmer's Attitude toward Organic Agriculture and Barriers for Converting to Organic Farming Systems: Research Insights. International Journal of Economic Plants, Volume 6(2), 097-103.

21. Shohreh Soltani, ,. H. (2014). Organic Agriculture in Iran: Farmers' Barriers to and Factors Influencing Adoption. Renewable Agriculture and Food Systems, Vol. 29, 126-134. 
22. M. Pradhan, B. T. (2017). Factors Influencing the Adoption of Organic Farming by the Farmers of North District of Sikkim. International Journal of Advanced Scientific Research \& Development, Vol. 04, 01-07.

23. Yadav, D. M. (2017). Towards A Healthier Nation: Organic Farming and Government Policies in India. International Journal of Advance Research and Development., Vol. 2, 153.

24. Bisoyi, B., \& Das, B. (2017). Organic Farming: A Sustainable Environmental Ingenuity for Biotechnological Intervention towards a Green World. International Journal of Innovative Research in Science, Engineering and Technology, Vol. 6, 2347-6710.

25. M. Romauli and L. Fauzia, J. Soc. Econ. Agric. Agribus. 3, (2014).

26. S. Suwanmaneepong, C. Kerdsriserm, K. Iyapunya, and U. Wongtragoon, J. Agric. Ext. 24, $71(2020)$.

27. P. Aditiawati, M. Rosmiati, and D. Sumardi, Sosiohumaniora 162, 184 (2014).

28. O. T. Damba, I. G. K. Ansah, S. A. Dankoh, A. Alhassan, G. R. Mullins, K. Yussif, M. S. Taylor, B. K. Tetteh, and M. Appiah-Twumasi, Technol. Soc. 62, (2020).

29. Y. Surdianto and N. Sutrisna, Petunjuk Teknis Budidaya Padi Organik, 2015.

30. Han, G. (2020). Motivations, challenges, benefits, and educational needs associated with organic grain Farming Adoption in Lowa. Lowa State University, 14.

31. E. M. Rogers, in Third Ed. (The Free Press, New York, 1971).

32. Soekartawi, Prinsip Dasar Komunikasi Pertanian (Universitas Indonesia (UI-Press), Jakarta, 1988).

33. T. A. Amala, D. Chalil, and L. Sihombing, J. Agric. Agribus. Socioecon. 2, (2013).

34. Sugiyono, Metode Penelitian Kuantitatif, Kualitatif, Dan R\&D (Alfabeta, Bandung, 2018).

35. Ahmadi, R. (2014). Metodelogi Penelitian Kualitatif. Ar-Ruz Media, Yogyakarta

36. G. Feder, R. E. Just, and D. Zilberman, Econ. Dev. Cult. Chage 33, 255 (2018).

37. S. O. Sennuga, T. O. Fadiji, and H. Thaddeus, J. Food, Agric. Environ. 6, 382 (2020).

38. David W. Crowder, J. P. (2014). Financial Competitiveness of Organic Agriculture on a Global Scale. PNAS, Vol. 112, 7611-7616.

39. Sennuga, Olayemi, S., Fadiji, Oduntan, T., Thaddeus, \& Hellen. (2020). Factors Influencing Adoption of Improved Agricultural Technologies (IATs) Among Smallholder Farmers in Kaduna State, Nigeria. International Journal of Agricuktural Education and Extension, Vol. 6(2), 382-391.

40. S. M. Chege, Technol. Anal. Strateg. Manag. 32, (2020).

41. Suwanmaneepong, S. K. (2020). Farmers' Adoption of Organic Rice Production in Chachoengsao Province, Thailand. Journal of Agricultural Extension, Vol. 24, 72.

42. B. Dhehibi, U. Rudiger, H. P. Moyo, and M. Z. Dhraief, Sustain. 12, (2020).

43. Azam, M. S., \& Shaheen, M. (2019). Decisional Factors Driving Farmers to Adopt Organic Farming in India: a Cross-Sectional Study. International Journal of Social Economics, Volume 46, 562-590. 
44. Opoku, P. D., Bannor, R. K., \& Kyeremeh, H. O. (2020). Examining the Willingness to Produce Organic Vegetables in the Bono and Ahafo Regions of Ghana. International Journal of Social Economics, Volume 47, 619-641.

45. Sohani, S. (2019). Basic Concept and Key Characteristics of Organic Farming in India. International Journal of Scientific Research and Review, Volume 07, 1134.

46. gh A.P, S. P. (2020). Socio-Economic Attribute and Attitude of the Farmers Towards Organic Farmingin Eastern Uttar Pradesh. International Journal of Agriculture Sciences, Volume 12, 9966-9969. 